\title{
ETIKA JUAL BELI DALAM ISLAM
}

\section{Syaifullah M.S.}

IAIN Palu Jl. Diponegoro No. 23 Palu 94221

E-mail: syaifullahms@rocketmail.com

\begin{abstract}
Abstrak. Jual beli merupakan suatu sarana umat manusia untuk saling memenuhi kebutuhan masing-masing, di satu sisi penjual dapat menjadi pembeli, sementara disisi lainnya pembeli dapat menjadi penjual, hingga bertemu dengan pembeli yang terakhir yang bertindak sebagai konsumen. Dengan demikian, jual beli dapat sangat rentan terjadi manipulasi kepada sesuatu yang dinginkan oleh satu pihak agar dia mendapatkan keuntungan yang bahkan di luar hitungan rasional. Oleh karena itu, jual beli dalam Islam tidak dapat terlepas dari etika yang mesti dipegang oleh semua pihak demi menjaga kemashlahatan bagi semua kalangan, yang pada akhirnya terbentuk sistem pasar yang aman, damai serta jujur dan tentunya akan terhindar dari sistem aniaya yang akan merugikan semua pihak.
\end{abstract}

Abstract. Buying and selling is a means of mankind to meet the needs of each individual.On the one hand, the seller can be a buyer, and on the other hand, the buyer may be a seller,till he or she meets the latest buyer who acts as a consumer. Thus, buying and selling can be very susceptible to manipulation to something desired by one party in order to gain benefit even beyond rational matter. Therefore, buying and selling in Islam cannot be separated from ethics. The ethics must be held by all parties in order to maintain public interest for all people. The purpose to eastablish a safe, peaceful, and honest market system in order to avoid wrong-doing system that can be detrimental to all parties 
Kata Kunci: Etika, Jual-Beli, ijāb-qabūl

\section{PENDAHULUAN}

Islam sebagai agama telah diyakini oleh umat manusia hampir separuh dari penduduk bumi, di mana mereka meyakini adanya Tuhan yang esa dengan mentauhidkan Allah swt. sebagai Tuhan yang tidak beranak dan tidak diperanakan serta tidak membutuhkan bantuan dari makhluknya dan dapat melakukan kekuasaannya tanpa adanya campur tangan dari yang selainNya. Oleh Karena itu, umat Islam kemudian melakukan ritual untuk menghambakan diri kepada Allah sebagai kewajiban spiritual agar dapat masuk kedalam golongan orang yang saleh.

Di sisi lain Islam sebagai suatu norma moral, pada tatanan bermasyarakat dalam pranata sosial terkadang terlepas dari pola pikir dan pola tindak umatnya. Islam masih dianggap sebuah ajaran yang hanya mengajarkan dan bahkan memerintahkan umatnya untuk beribadah secara vertikal belaka, belum masuk ke dalam relung hati kaum muslimin untuk dilaksanakan secara kaffah dalam segala lini kehidupan, yang bukan hanya spiritual namun aktual sosial kemasyarakatan atau bermuamalah.

Kenyataan di atas mengakibatkan terkadang ditemukan orang yang sangat saleh menurut ukuran empiris spiritual, namun sangat jauh ketika dihubungkan dengan keberadaannya dalam bermuamalah yang seakan-akan tidak berhubungan antara ibadah vertikal dengan horisontal. Oleh karena itu, tulisan ini ingin memberikan gambaran norma atau etika dalam Islam yang berhubungan dengan sistem muamalah yang lebih khusus lagi pada jual beli, sehingga masalah dalam tulisan ini adalah bagaimana etika Islam dalam aturan jual beli, yang implikasinya bahwa sesungguhnya Islam telah memiliki secara sempurna aturan atau etika dalam berjual beli yang dapat mengantarkan umat Islam untuk menjadi saleh secara sosial dan bukan hanya sekedar saleh ritual. 
Syaifullah, M. S. : Etika Jual Beli...

\section{JUAL BELI DALAM ISLAM}

Jual beli dalam bahasa Arab berasal dari kata (البيع) yang artinya menjual, mengganti dan menukar (sesuatu dengan sesuatu yang lain). Kata (البيع) dalam bahasa arab terkadang digunakan untuk pengertian lawannya, yaitu kata : الثراء dengan demikian kata (البيع) berarti kata jual dan sekaligus berarti kata "beli". ${ }^{1}$

Secara terminologi terdapat beberapa definisi para ulama diantaranya oleh ulama Hanafiyah memberi pengertian dengan 'saling menukarkan harta dengan harta melalui cara tertentu', atau dengan makna 'tukar menukar sesuatu yang diingini dengan sepadan melalui cara tertentu yang bermanfaat.

Ulama Hanafiyah menjelaskan bahwa makna khusus pada pengertian pertama tadi adalah ijab dan kabul, atau juga bisa melalui saling memberikan barang dan menetapkan harga antara pembeli dan penjual. ${ }^{2}$ Sedangkan pada pengertian kedua menjelaskan bahwa harta yang diperjualbelikan itu harus bermanfaat bagi manusia, seperti menjual bangkai, minuman keras dan darah tidak dibenarkan. ${ }^{3}$

Sayid Sabiq mendefinisikan jual beli dengan arti 'saling menukar harta dengan harta atas dasar suka sama suka'. Sementara Imam al-Nawāwī menjelaskan bahwa jual beli adalah 'saling menukar harta dengan harta dalam bentuk pemindahan milik'. Defenisi ini tidak jauh berbeda dengan apa yang didefinisikan oleh Abū Qudāmah yaitu 'saling menukar harta dengan harta dalam bentuk pemindahan milik dan pemilikan'.

${ }^{1}$ M. Ali Hasan, Berbagai Macam Transaksi dalam Islam (Cet. ke-1; Jakarta: PT RajaGrafindo Persada, 2003), h. 113

${ }^{2}$ Ibid., h. 114

${ }^{3}$ Wahbah al-Zuhaili, al-Fiqh al-Islām wa Adillatuh, Jilid IV, (Beirut: Dār al-Fikr, 1989), h. 345 
Sementara menurut Hasbi ash-Shiddieqy jual beli adalah akad yang terdiri atas penukaran harta dengan harta lain, maka terjadilah penukaran dengan milik tetap. ${ }^{4}$

Dari penjelasan beberapa ulama diatas, "hak milik dan pemilikan ditekankan", sebab ada tukar menukar harta yang sifatnya tidak harus dimiliki seperti sewa menyewa.

Kata harta dalam beberapa pengertian di atas, terjadi perbedaan pendapat antara mazhab Hanafi dan jumhur ulama. Menurut jumhur ulama yang dimaksud harta adalah materi dan manfaat. Oleh karena itu, manfaat dari suatu benda boleh diperjualbelikan. Sedangkan ulama mazhab Hanafi berpendapat, bahwa yang dimaksud dengan harta adalah sesuatu yang mempunyai nilai. Oleh sebab itu manfaat dan hak-hak, tidak dapat dijadikan objek jual beli. Adapun jual beli yang dimaksud dalam tulisan ini adalah transaksi yang mengandung dua unsur yaitu ijab dan qabul.

Jual beli yang merupakan kegiatan tolong menolong antara sesama manusia mempunyai landasan yang amat kuat dalam Islam, baik dari Alquran, Sunnah dan Ijma'. Allah swt. berfirman:

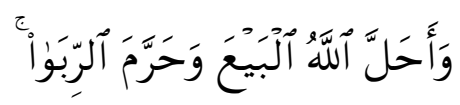

Dan Allah telah menghalalkan jual beli dan mengharamkan riba (Q.S. .alBaqarah (2): 275). ${ }^{5}$

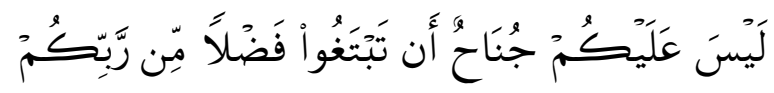

Tidak ada dosa bagimu untuk mencari karunia (rezeki hasil perniagaan) dari tuhanmu (Q.S. .al-Baqarah (2):198). ${ }^{6}$

${ }^{4}$ Hasbi Ash-Shiddieqy, Pengantar Fiqh Maumalat, (Cet. ke-3; Jakarta: Bulan Bintang, 1989), h. 97

${ }^{5}$ Departemen Agama RI, Al-Qur'an dan Terjemahnya. (Bandung: Yayasan Penyelenggara Penterjemah Al-Qur'an, 2005), h. 48 


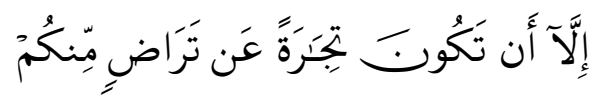

Kecuali dengan jalan perniagaan yang berlaku dengan suka sama suka diantara kamu (Q.S. al-Nisā’ (4):29).

Di dalam salah satu hadis Rasulullah saw. dijelaskan:

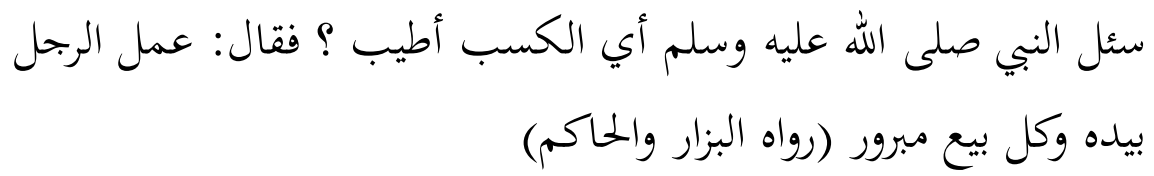

Nabi Muhammad saw pernah ditanya. Apakah profesi yang paling baik? Rasulullah menjawab: "Usaha tangan manusia tersendiri dan setiap jual beli yang diberkati”. (H.R. al-Barzar dan Al-Hakim)

Para ulama fiqh ber'ijma bahwa hukum dari jual beli adalah mubah (boleh). Karena manusia sebagai makhluk sosial yang saling membutuhkan satu sama lain. Oleh karena itu, hikmah dari jual beli itu sendiri dapat membantu manusia untuk kelangsungan hidupnya. Dan manusia tidak bisa hidup tanpa saling membantu sesamanya. Akan tetapi Imam al-Syațibī mengatakan bahwa hukum jual beli bisa berubah dari mubah menjadi wajib dalam situasi tertentu.

Sebagai contoh, bila suatu waktu terjadi praktek ihtikar (penimbunan barang), sehingga persediaan terbatas yang mengakibatkan harga dipasaran melonjak dari harga biasanya. Apabila terjadi praktek semacam itu maka pemerintah boleh memaksa para pedagang untuk menjual barang-barang sesuai harga pasar sebelum terjadi pelonjakan harga dari barang tersebut. Dan menjadi wajib bagi para pedagang untuk mentaati perintah pemerintah.

Praktek semacam di atas tersebut banyak kita jumpai di masyarakat kita, seperti penimbunan beras, gula pasir, BBM, yang

${ }^{6}$ Ibid., h. 32

${ }^{7}$ Ibid., h. 84 
mengakibatkan para pelaku penimbunan menjadi jutawan dalam keadaan mendadak dan membuat banyak rakyat menjadi melarat.

\section{RUKUN DAN SYARAT JUAL BELI}

Jual beli yang sesuai dengan Syariat Islam harus memenuhi rukun dan syarat dari jual beli sementara rukun dan syarat adalah sesuatu yang harus dipenuhi agar jual beli itu dipandang sah. Karena jual beli merupakan suatu akad, maka harus dipenuhi rukun dan syaratnya.

Mengenai rukun dan syarat jual beli, para ulama berbeda pendapat. Menurut Mazhab Hanafi rukun jual beli hanya ijab dan Kabul. Menurut ulama mazhab Hanafi yang menjadi rukun jual beli hanyalah kerelaan antara kedua belah pihak untuk berjual beli. Ada dua indikator (qarinah) yang menunjukkan kerelaan dari kedua belah pihak, yaitu dalam bentuk perkataan (ijāb dan qabūi) dan dalam bentuk perbuatan, yaitu saling memberi (penyerahan barang dan penerimaan uang) untuk yang kedua dalam ilmu fiqih disebut dengan istilah بيع المعاطة.

Jumhur ulama membagi rukun jual beli menjadi empat:

- Orang yang berakad.

- Sighat.

- Ada barang yang dibeli.

- Ada nilai tukar pengganti barang.

Namun mazhab Hanafi menganggap bahwa orang yang berakad, barang yang dibeli, dan nilai tukar barang $(a, c, d)$ di atas termasuk syarat jual beli, bukan rukun. Jumhur ulama menjelaskan bahwa syarat jual beli sesuai dengan rukun jual beli itu yang disebutkan di atas adalah sebagai berikut:

${ }^{8}$ M. Ali Hasan, Berbagai Macam..., h. 118 


\section{Syarat orang yang berakad}

Ulama fiqih sepakat, bahwa orang yang melakukan transaksi jual beli harus memenuhi syarat-syarat:

- Berakal. Dengan syarat tersebut maka anak kecil yang belum berakal tidak boleh melakukan transaksi jual beli, dan jika telah terjadi transaksinya tidak sah. Jumhur ulama berpendapat, bahwa orang yang melakukan transaksi jual beli itu harus telah akil baliqh dan berakal. Apabila orang yang bertransaksi itu masih mumayyiz, maka transaksi jual beli itu tidak sah. Sekalipun mendapat izin dari walinya.

- Orang yang melakukan transaksi itu, adalah orang yang berbeda. Maksud dari syarat tersebut adalah bahwa seorang tidak boleh menjadi pembeli dan penjual pada waktu yang bersamaan.

\section{Syarat yang terkait dengan $i j a \bar{b} b$ dan $q a b \bar{u} l$.}

Ulama fiqih sepakat bahwa urusan utama dalam jual beli adalah kerelaan antara penjual dan pembeli. Kerelaan ini dapat terlihat pada saat transaksi berlangsung. Oleh karena itu, ijāb qabūl harus diungkapkan dengan jelas sehingga tidak terjadi penipuan dan dengan ijab Kabul dapat mengikat kedua belah pihak. ${ }^{9}$

Apabila ijāb-qabūl telah diucapkan dalam transaksi, secara otamatis kepemilikan barang dan uang telah berpindah tangan. Ulama fiqih menjelaskan bahwa syarat dari ijāb-qabūl adalah sebagai berikut:

- Jumhur ulama berpendapat bahwa orang yang mengucapkannya harus telah akil baligh dan berakal, sedangkan menurut Ulama Mazhab Hanafi mensyaratkan hanya telah berakal saja.

${ }^{9}$ Ibid., h. 120 
- Kabul harus sesuai dengan ijab. Sebagai contoh : "saya jual mobil ini dengan harga seratus juta rupiah", lalu pembeli menjawab : "saya beli dengan harga seratus juta rupiah".

- Ijab dan Kabul harus dilakukan dalam satu transaksi, dan tidak boleh terpisah. Maksudnya kedua belah pihak yang melakukan transaksi harus hadir pada waktu yang bersamaan. ${ }^{10}$

\section{Syarat yang diperjual belikan.}

Syarat yang diperjualbelikan, adalah sebagai berikut:

- Barang itu ada, atau tidak ada ditempat, tetapi pihak penjual menyatakan sanggup untuk mengadakan barang itu

- Barang tersebut dapat dimanfaatkan dan bermanfaat bagi manusia. Oleh karena itu keluar dari syarat ini adalah menjual khamar, bangkai haram untuk diperjualbelikan, karena tidak bermanfaat bagi manusia dalam pandangan syara'

- Milik seseorang. Maksudnya adalah barang yang belum milik seseorang tidak boleh menjadi objek jual beli, seperti menjual ikan yang masih di laut, emas yang masih dalam tanah, karena keduanya belum menjadi milik penjual.

- Dapat diserahkan pada saat akad berlangsung, atau pada waktu yang telah disepakati.

\section{Syarat nilai tukar (harga barang)}

Nilai tukar suatu barang merupakan salah satu unsur terpenting.Yang pada zaman sekarang disebut dengan uang. Ulama fiqih memberikan penjelasan bahwa syarat nilai tukar adalah sebagai berikut:

- Harga yang disepakati kedua belah pihak harus jelas jumlahnya.

\section{${ }^{10} \mathrm{Ibid}$.}


- Dapat diserahkan pada saat waktu transaksi, sekalipun secara hukum seperti pembayaran dengan cek atau kartu kredit. Apabila barang dibayar kemudian (berhutang), maka waktu pembayarannya harus jelas waktunya.

- Jika jual beli itu dilakukan dengan cara barter, maka barang yang dijadikan nilai tukar, bukan barang yang diharamkan syara' seperti babi dan khamar.

Itulah syarat-syarat jual beli yang berkaitan dengan rukunrukun jual beli. Disamping syarat-syarat yang telah penulis paparkan di atas, ulama fiqh juga mengemukakan beberapa syarat lain.

Ulama fiqih menyatakan, bahwa suatu jual beli baru dianggap sah, bila terpenuhi dua hal: Pertama, jual beli tersebut terhindar dari cacat. Baik dari segi barang yang diperjualbelikan tidak jelas, dan jual beli tersebut mengandung unsur paksaan dan penipuan sehingga mengakibatkan jual beli tersebut rusak.

Kedua, jika barang yang menjadi objek jual beli tersebut merupakan barang yang bergerak, maka barang tersebut dengan otomatis menjadi milik pembeli dan harga dari barang tersebut menjadi milik penjual. Namun jika barang yang menjadi objel jual beli merupakan barang yang tidak bergerak, maka barang tersebut boleh dikuasai setelah surat-menyuratnya sudah diselesaikan sesuai dengan ketentuan yang berlaku ditempat tersebut. ${ }^{11}$

Selanjutnya, transaksi jual beli baru dapat dilaksanakan jika yang berakad mempunyai kekuasaan penuh dalam bertransaksi. Kekuasaan yang dimaksud di sini adalah bahwa orang yang berakad adalah punya wewenang penuh terhadap barang yang menjadi objek transaksi. Apabila kekuasaan tidak dimiliki oleh

\footnotetext{
${ }^{11}$ Ibid., h.125
} 
orang yang bertransaksi, maka jual beli tersebut tidak dapat dilakukan.

Jika proses transaksi terbebas dari segala macam khiyar, maka transaksi tersebut akan mengikat terhadap kedua belah pihak. Khiyar yang dimaksud di sini adalah hak pilih untuk meneruskan atau membatalkan jual beli. Dan jual beli yang masih mempunyai hak khiyar maka jual beli tersebut belum mengikat dan dapat dibatalkan. Jika semua syarat-syarat diatas terpenuhi, maka suatu proses jual beli telah dianggap sah. Dan bagi kedua belah pihak tidak dapat lagi membatalkannya.

\section{ETIKA JUAL BELI}

Islam dengan segala kelebihan yang dimilikinya selain karena ia adalah sebuah agama spiritual, Islam juga adalah konsep agama sosial yang diterapkan dalam segala sendi kehidupan manusia. Konsep sosial Islam sangat jelas memberikan batasan dan kemampuan manusia untuk berekspresi dan berinovasi yang tidak keluar dari norma etika moral yang dikenal dengan istilah akhlak karimah yang juga didalamnya berhubungan dengan bagaimana umat manusia itu mejalankan sistem kemasyarakatannya yang disebut dengan bermuamalah.

Dalam bermuamalah ini kemudian secara mikro mengatur tentang perpindahan kepemilikian yang disebut dengan jual beli. Seorang pengusaha muslim tidak akan mencekik konsumen dengan mengambil laba sebanyak-banyaknya. ${ }^{12}$ Demikian pula semestinya seorang yang memiliki kemampuan untuk membeli suatu barang tentu tidak harus menawarnya sampai hilang batas rasionalitas akan keuntungan yang dapat diraup oleh pedagang. Oleh karena itu, keseimbangan sangat diperlukan oleh masingmasing orang yang berperan hingga terjadinya proses jual beli tersebut.

${ }^{12}$ Yusuf Qordhawi, Norma dan Etika Ekonomi Islam (Jakarta: Gema Insani, 1997), h. 36. 
Etika dalam berbisnis seperti yang telah diteladani Rasulullah yaitu Nabi Muhammad saw. di mana sewaktu muda ia berbisnis dengan memperhatikan kejujuran, kepercayaan dan ketulusan serta keramah-tamahan. ${ }^{13}$ Kemudian mengikutinya dengan penerapan prinsip bisnis dengan nilai șiddīq, amānah, tablīgh, dan fațānah, serta nilai moral dan keadilan.

Sekarang ini terdapat kecenderungan berbisnis yang kurang sehat antar sesama pengusaha muslim atau bahkan dengan yang lainnya, sebagai contoh misalnya, pengusaha yang menjatuhkan dan menjelek-jelekkan rekan maupun produk dari apa yang mereka usahakan, sehingga jika tidak diatasi, tentu akan menimbulkan persoalan di kalangan dunia usaha yang tidak sehat.

Sifat yang diajarkan Islam dengan segala akhlak yang mulia (mahmudah) merupakan sifat yang sebenarnya itu pula yang mesti diterapkan oleh para pengusaha podusen maupun konsumen atau baik penjual maupun pembeli sifat-sifat seperti 'berlaku jujur (al-amānah), berbuat baik kepada kedua orang tua (birr al-wālidain), memelihara kesucian diri (al-iffah), kasih sayang (al-rahmān dan al-barrì), berlaku hemat (al-iqtiṣād), menerima apa adanya dan sederhana (qanā'ah dan zuhud), perikelakuan baik (Iḥsān), kebenaran (șiddīq), pemaaf ('afu), keadilan ('ad), keberanian (ayajā'ah), malu (hayā), kesabaran (sabr), berterima kasih (Syukūr), penyantun (hindun), rasa sepenanggungan (muwāsaț), kuat (quwwah)' ${ }^{14}$ adalah sifat yang mesti ditetapkan oleh umat Islam secara umum di masyarakat, dan sifat itu pula yang menjadikan Nabi Muhammad sebagai sorang pedagang yang berhasil tatkala melakukan perjalanan

\footnotetext{
${ }^{13}$ Muhammad Abd Mannan, Teori dan Praktek Ekonomi Islam, (Yogyakarta: Dana Bakti Wakaf, 1993), h. 288

${ }^{14}$ Sudarsono, Etika Islam tentang Kenakalan Remaja (Jakarta: Bina Aksara, 1989), h. 41
} 
niaga baik untuk barang bawaan pamannya ataupun Khadijah sebelum menjadi istrinya.

Contoh yang diberikan oleh Muhammad sebelum dan setelah menjadi nabi dengan sifat-sifat kebaikan yang disebutkan dalam pernyataannya bahwa; Dia tidak diutus kecuali untuk menyempurnakan akhlak mulia, adalah suatu ha yang termat besar sifatnya dalam sumbangsihnya membangun peradaban dunia hingga kini. Kemuliaan yang telah dicontohkan beliau menjadi simbol atau kode dari etika atau akhlak yang mesti dijadikan tauladan bagi siapa saja terlebih bagi umat Islam yang mau berhasil dalam kehidupan secara umum atau dalam berniaga.

Sifat yang melekat itu menjadikan keberhasilan yang tiadataranya bagi kemasyhuran Islam di kemudian hari yang berimbas pada kehidupan ekonomi. Sifat yang melekat itu dijadikan kode etik bagi umat Islam dan diterapkan dalam hal jual beli.

Adapun sifat dan perilaku itu dapat disebutkan secara ringkas diataranya yaitu:

- Kejujuran. ${ }^{15}$ Cakupan jujur ini sangat luas, seperti tidak melakukan penipuan, tidak menyembunyikan cacat pada barang dagangan, menimbang barang dengan timbangan yang tepat, dan lain-lain.

- Tidak bersumpah palsu. Sumpah palsu sangat tidak dibenarkan dalam Islam, apalagi dengan maksud agar barang jualannya cepat laku dan habis terjual. Islam sangat mengecam hal itu karena termasuk pekerjaan yang tidak disukai dalam Islam. ${ }^{16}$

${ }^{15}$ Hulwati, Transaksi Saham di Pasar Modal Indonesia Perspektif Hukum Ekonomi Islam (Yogyakarta: UII Press, 2001), h. 44-45, lihat juga Muhammad Saifullah, "Etika Bisnis Islami dalam Praktek Bisnis Rasulullah" dalam Jurnal Walisongo, Vol 19, No. 1, (Mei 2011), h. 146

${ }^{16}$ Muhammad Abd Mannan, Teori dan Praktek..., h. 288 
- Amānah. Amānah adalah bentuk mașdar dari amuna, ya'munu yang artinya bisa dipercaya. Ia juga memiliki arti pesan, perintah atau wejangan. Dalam konteks fiqh, amānah memiliki arti kepercayaan yang diberikan kepada seseorang berkaitan dengan harta benda.

- Takaran yang benar. Menakar yang benar dan sesuai dianggap tidak mengambil hak dari orang lain, karena nilai timbangan dan ukuran yang tepat serta standar benar-benar harus diutamakan dan ini adalah perintah Alquran yang terdapat dalam Q.S. al-Muțaffifīn. ${ }^{17}$

- Gharar. ${ }^{18}$ Gharar menurut bahasa berarti al-khatar yaitu sesuatu yang tidak diketahui pasti benar atau tidaknya, atau biasa disebut belum pasti yang dapat merugikan pihak-pihak yang bertransaksi diantara mereka atau yang biasa disebut dengan spekulatif. Selain itu ada bentukan spekulatif yang diebsut dengan istilah Juzaf yaitu jual beli yang biasanya suatu barang ditakar tetapi kemudian tidak dilakukan dengan takaran. ${ }^{19}$

- Tidak melakukan judi dalam jual beli semisal dengan cara melemparkan kepada suatu barang yang akan dibeli jika kena maka jadi pembelian jika tidak maka pembelian tidak terjadi namun ongkos dari harga telah terbayarkan kepada penjual. ${ }^{20}$

- Tidak melakukan al-ghab (penipuan) dan tadlīs menyembunyikan kondisi utuh dari barang baik secara kualitas maupun kuantitas). ${ }^{21}$

\footnotetext{
${ }^{17}$ Ibid, h. 289, lihat juga Hulwati, Transaksi Saham..., h. 46

${ }^{18}$ Muhammad dan Lukman Fauroni, Visi Alquran tentang Etika dan Bisnis, (Jakarta: Salemba Diniyah, 2002), h. 156-157

${ }^{19}$ Abdullah Al Mushlih dan Shalah Ash-Shawi, Fikih Ekonomi Keuangan Kontemporer, (Jakarta: Darul Haq, 2004), h. 93-95

${ }^{20}$ Muhammad dan Lukman Fauroni, Visi Alquran..., h. 156-157

${ }^{21}$ Ibid., h. 157-158
} 
- Menjauhi Ikhtikar atau penimbunan barang. Penimbunan ini tidak diperbolehkan karena akan menimbulkan kemadharatan bagi masyarakat karena barang yang dibutuhkan tidak ada di pasar. Tujuan penimbunan dilakukan dengan sengaja sampai dengan batas waktu untuk menunggu tingginya harga barangbarang tersebut. ${ }^{22}$

- Saling menguntungkan. Prinsip ini mengajarkan bahwa dalam bisnis para pihak harus merasa untung dan puas. Etika ini pada dasarnya mengakomodasi hakikat dan tujuan bisnis. Seorang produsen ingin memperoleh keuntungan, dan seorang konsumen ingin memperoleh barang yang bagus dan memuaskan, maka sebaiknya bisnis dijalankan dengan saling menguntungkan.

- Larangan Menjual Barang yang Haram, Islam melarang menjual barang yang memeang karena haram secara zatnya. Hal itu dikarenakan akan berdampak kepada umat manusia yang tidak akan mendapatkan berkah dari jual beli atau bahkan berbahaya pada diri manusia itu. ${ }^{23}$

- Larangan mengambil Riba. Riba dengan segala jenisnya yang mengambil kelebihan dari keuntungan yang tidak sah atau selisih dari pertukaran komoditi yang berbeda takaran dan jenisnya diharamkan dalam Islam. ${ }^{24}$

- Larangan menawar barang yang sedang ditawar oleh orang lain yaitu ketika suatu barang yang talah disepakati harganya antara penjual dan pembeli yang pertama tiba-tiba datang pembeli yang kedua menawar dengan harga yang lebih mahal,

${ }^{22}$ Ibid., h. 158-161

${ }^{23}$ Hulwati, Transaksi Saham..., h 46

${ }^{24}$ Abdullah Al Mushlih dan Shalah Ash-Shawi, Fikih Ekonomi..., h. 11-14, lihat juga Hulwati, Ibid., h. 47 
lalu penyerahan barang diberikan kepada pembeli yang kedua. $^{25}$

- Larangan berjualan ketika dikumandangkan azan Jumat. Hal ini berdasarkan Alquran pada surah Al Jumuah ayat 9, yang memberikan batasan ketika telah berkumandang azan Jumat haruslah perniagaan dihentikan untuk menghargai masuknya Ibadah Jumat. ${ }^{26}$

Dari poin-poin di atas, dapat dilihat bahwa Islam begitu lengkap mengatur sistem etik yang akan menjaga hak dan kewajiban dari penjual dan pembeli, bahkan dalam tulisan ini baru sebagian kecil yang dapat diungkapkan dari sekian banyak sistem etika yang diberlakukan oleh Islam untuk mengatur agar terlindunginya hak dan kewajiban atas dasar kesepakatan melakukan jual beli antara satu dengan yang lainnya.

Selain poin-poin yang secara langsung mengatur sistem etikanya, sebenarnya rukun dan syarat yang melekat pada sistem jual beli adalah bagian dari norma yang mengatur secara langsung untuk dapat memberikan ikatan dan jaminan akan transaksi yang dilakukan dapat memberikan kepastian keamanan dan kenyamanan bagi mereka yang bertransaksi.

\section{PENUTUP}

Etika Jual beli dalam Islam sangatlah luas yang mencakup segala hal yang bersangkut paut dengannya. Etika Islam mengatur agar perpindahan barang dari tangan satu ke tangan lainnya secara sah dan halal serta baik bagi pihak yang bertransaksi.

Islam tidak melarang adanya inovasi dan kreasi disegala lini dalam jual beli, namun Islam memberikan sinyal-sinyal yang harus diikuti agar tidak merusak tatanan bermasyarakat, sehingga silaturrahmi diantara manusia sesuai dengan tujuan

${ }^{25}$ Abdullah Al Mushlih dan Shalah Ash-Shawi, ibid., h. 109

${ }^{26}$ Ibid., h. 116 
diciptakan berbeda antara yang satu dengan lainnya dapat tercapai yang tentunyan untuk saling melengkapi.

Etika Islam diterapkan sebagai solusi peradaban yang bermartabat dari sekian banyak sistem ekonomi yang masih mengandung unsur aniaya di dalamnya, apakah aniaya itu dalam bentuk fisik, psikis mapun harta benda, untuk dapat mengangkat martabat umat manusia secara umum dan khususnya bagi umat Islam.

\section{DAFTAR PUSTAKA}

Al Mushlih, Abdullah dan Shalah Ash-Shawi, Fikih Ekonomi Keuangan Kontemporer, Jakarta: Darul Haq, 2004.

Ash-Shiddieqy, Hasbi, Pengantar Fiqh Maumalat, Cet. ke-3; Jakarta: Bulan Bintang, 1989.

az-Zuhaili, Wahbah, al-Fiqh al-Islam wa Adillatuh, Jilid IV, Beirut: Dar al-Fikr, 1989.

Departemen Agama RI, Alquran dan Terjemahnya, Bandung: Yayasan Penyelenggara Penterjemah Alquran, 2005.

Hasan, M. Ali, Berbagai macam transaksi dalam Islam, Cet ke-1; Jakarta: PT RajaGrafindo Persada, 2003.

Hulwati, Transaksi Saham di Pasar Modal Indonesia Perspektif Hukum Ekonomi Islam, Yogyakarta: UII Press, 2001.

Mannan, Muhammad Abd, Teori dan Praktek Ekonomi Islam, Yogyakarta: Dana Bakti Wakaf, 1993.

Muhammad dan Lukman Fauroni, Visi Alquran tetnang Etika dan Bisnis, Jakarta: Salemba Diniyah, 2002.

Qordhawi, Yusuf, Norma dan Etika Ekonomi Islam, Jakarta : Gema Insani, 1997. 
Syaifullah, M. S. : Etika Jual Beli...

Saifullah, Muhammad, "Etika Bisnis Islami dalam Praktek Bisnis Rasulullah" dalam Jurnal Walisongo, Vol. 19, No. 1, (Mei 2011).

Sudarsono, Etika Islam tentang Kenakalan Remaja, Jakarta: Bina Aksara, 1989. 
Vol. 11, No. 2, Desember 2014: 371-387 